\section{Disease and death at Shanidar}

\section{Michael Day}

The Shanidar Neandertals.

By Erik Trinkaus.

Academic: 1983. Pp.502. \$47.50, £35.

FOR some inexplicable reason the Shanidar Neanderthal remains from northern Iraq have never enjoyed the publicity that they seem to deserve. This has now been remedied by Erik Trinkaus; he has undertaken a careful study of the human bones, the results of which form the bulk of this monograph. The geology, archaeology, fauna and dating of the site are all touched upon in order to set the finds in context, but this brief treatment raises almost as many questions as it attempts to answer.

The site is a vast limestone cavern over $50 \mathrm{~m}$ wide and $45 \mathrm{~m}$ deep, set in a valley wall, which has given shelter to men and animals for many thousands of years. The excavations conducted in the 1950 s by Solecki and Senyurek went down for $14 \mathrm{~m}$ through five "strata" and recovered Mousterian tools, a modern fauna and nine Neanderthal skeletons, two of which were of infants. The dating of the remains quoted by Trinkaus is of the order of 60,000 70,000 years BP on the evidence of two radiocarbon dates from an upper layer and "continuous sedimentation" - tenuous grounds for any chronological opinion, as the author openly admits.

The strength of the monograph lies in the meticulous and exhaustive descriptions of the bones and teeth, and in the following attempts to assign age, sex and stature to each skeleton on the basis of anatomical observations, comparative measurements and the application of formulae. The abundance of skeletal pathology (both traumatic and degenerative) provides opportunities for speculation as to how the injuries were sustained and how the group cared for its wounded members. These aspects of the work go some way to leaven the lump of pure anatomical description and "morphometrics".

The phylogenetic considerations quoted for this group are few. The Shanidar Neanderthals are said to be indistinguishable from European and Near Eastern Neanderthals from other sites in terms of the face, the anterior dental dimensions and the postcranial skeleton. Not surprisingly, this also turns out to be Trinkaus's final conclusion. It may be, therefore, that we are getting some inkling of why the remains have never attracted the interest that at first sight they merit perhaps they do not have much to contribute to our understanding of human evolution. If that is the case, then in compensation this detailed study does attempt to bring out some oblique sidelights on being a Neanderthaler. It is

injuries on several skeletons, does provide some evidence of the behaviour of the Neanderthals from Shanidar - survival of the infirm is a behavioural trait that implies a level of social cohesion not previously identified from equivalent sites. Other sidelights on Neanderthal life in the Middle East include a suggestion of infant headbinding, intentional burial and the nonmasticatory use of teeth.

Two final questions that are always asked about Neanderthals - were they taurodont and did they have a stooping bent-kneed gait? The answers are yes to the first question and no to the second. The anatomical opinion given on their locomotion is that they enjoyed "normal human striding bipedal gaits" - that is, I assume, when they were not on crutches! $\square$ survival, the second is cranial damage followed by hemiplegia, the third an old nerve injury that led to paralytic atrophy of the arm. Each of these explanations, and indeed the presence of severe, yet healed,

Michael Day is Professor of Anatomy at St Thomas's Hospital Medical School, University of London.

\section{Our man in Africa}

\section{Paul A. Colinvaux}

\section{The Ecological Century: A Personal} Appraisal.

By E. Barton Worthington.

Oxford University Press: 1983. Pp.206.

£13.50, \$27.50.

IT so happened that the collapse of the British Empire coincided with the final emergence of ecology as a major intellectual discipline. E. B. Worthington had a career as a very British public servant through these years of change. He has left a memoir that must be of immense value to future historians; a candid statement of a career at the top while the African Empire fell and administrators learned to listen to ecologists.

Worthington began expeditioning from Cambridge in 1927. For six years he divided his time between the Cam and the African Rift or the Nile, in the company of such men as L.C. Beadle and Vivian Fuchs. His interest in fisheries, and his view of lakes as units of production, at once marked him as one of the very few at that time with both experience of Africa and scientific instincts for resource management. Julian Huxley passed his name to a proconsul of the Indian Empire (Hailey), then charged with a survey of the resources of Africa, and Worthington became secretary to that project for four years. Home again, he spent a decade as the first director of the Fresh Water Biological Association's laboratory, before returning to Africa on commission after commission. Then to the directorship of the Nature Conservancy until 1964, broken short for a last decade (1964-1974) as Secretary to the International Biological Programme, before becoming a natural choice as environmental advisor to various British industrial consortia. All the stages of this remarkable career are set out with a frankness that illuminates the whole human system in which Worthington lived.

The opportunities given by the Empire to field naturalists were such as dreams are made of, and the young Worthington took full advantage of them. The Cambridge cachet opened frontiers, government houses, guest houses and barracks. To a generation that has known graduate students to be machine-gunned and research travellers thrown into sordid gaols for they knew not what, this is a remote past. I once caught the tail end of it myself (also on an expedition from Cambridge); on coming upon a remote African village, a person ran out to assure me that the guest house was ready and they would start cooking supper - blissful world. Worthington revelled in it and tells us of the life as if it were the most normal of existences.

The progression from Cambridge student to chairman of committees came naturally. The friends made on expeditions all rose to eminence in their respective fields, but more than all of them Worthington seems to have combined the skills of the mediator with an early grasp of the "design with nature" approach to practical ecology. This placed him in the councils of the governors and these pages will convey to future historians more than a hint of the social milieu and attitude of the British to their colonies in these transitional years.

But the defects of the old system show through clearly enough. People trained in science were extraordinarily few in number, so that the handful who were in at the start were turned to by officialdom again and again. Each appointment of Worthington's long career seems to have come about at the invitation of a friend of youth, even to the final one with IBP across a dinner table, "how would you like to. ...". 